\title{
The Impact of Social Brand Engagement on Customer- Based Brand Equity in Higher Education: An Empirical Study in Sri Lanka
}

\author{
Charitha Harshani Perera ${ }^{1}$, Dr. Rajkishore Nayak $^{2}$, Dr. Long Thang Van Nguyen ${ }^{3}$ \\ ${ }^{1}$ School of Business and Management, RMIT University, Vietnam \\ ${ }^{2}$ School of Communication \&Design, RMIT University, Vietnam \\ ${ }^{3}$ School of Communication \& Design, RMIT University, Vietnam
}

\begin{abstract}
The widespread of social media facilitates many changes in the higher education sector including the branding activities of Higher Education Institutions (HEIs) in emerging countries. This triggered a need for this research to deepen our understanding of students' social engagement with HEI brands and its importance in developing customer-based brand equity (CBBE) for the HEIs. Drawing from social information processing theory, this paper examines the influence of Social Brand Engagement (SBE) on CBBE, and brand choice intention of HEIs taking into consideration the mediating effects of brand credibility, and electronic word-ofmouth (eWOM) from the perspective of undergraduates. Employing a quantitative survey design, 384 undergraduates from Sri Lankan HEIs were selected for this study. While SBE positively influences CBBE, this relationship is significantly mediated by brand credibility and eWOM. The findings also indicated that CBBE encourages the students to increase their intention in selecting an HEI to pursue their higher studies. Further, this study provides insights into the potential role of SBE and CBBE in advancing the broader understanding of brand relationship management, brand engagement, and social media research. Our conceptualization of SBE suggests a need for managers to adopt creative strategies that will arouse customers' interest and attention to participate in such interactions.
\end{abstract}

Keywords: social brand engagement, customer-based brand equity, higher education, emerging countries 


\section{Introduction}

In today's global marketplace, the role of brand management has been elevated to a new level of importance (M'zungu et al., 2019). Brands as powerful assets represent the essence of a company; therefore, they must be carefully developed and managed (Leijerholt et al., 2019). Since the brand is one of a company's most valuable intangible assets, a brand functions as a powerful differentiator for the business and as a decision-making tool for customers (Ökten et al., 2019). Branding efforts are no longer limited to "consumer products." Firms and organizations in various service industries have been trying to utilize branding strategies to build stronger brands (Ottman, 2017). In this regard, Higher Education Institutions (HEIs) are not exceptions; they have also begun to realize the need to develop sustainable brand strategies (Endo et al., 2019). In fact, branding has increasingly become a strategic imperative for HEIs in order to develop meaningfully differentiated brands to communicate their strengths.

As HEIs are considered the students as 'customers', branding and marketing purposes has raised much debate in the higher education sector (Guilbault, 2018). Although the HEIs could not survive without a proven marketing practice such as branding, HEIs took some time to warm to this concept; when they did, it was not without some controversy (ÁlvarezMendiola and González-Ledesma, 2018). Since the higher education market has become highly competitive, domestically as well as internationally, HEIs are looking to counteract the new market forces primarily by differentiating themselves in the global arena (Lomer et al., 2018). As a result of recent globalization and increased competition, branding and brand equity have received a great deal of attention, where the ultimate goal of all branding strategies is to build strong brand equity for HEIs (Kaushal and Ali, 2019). Brand equity assesses the competitive relationships among a number of brands by identifying the set of perceptions, preferences, and associations that customers have about the brands (Iglesias et al., 2019). Similarly, brand equity enables the HEIs' marketers to add symbolic meaning to their services in order to achieve the required differentiation (Kaushal and Ali, 2019).

The concepts of brand equity and social brand engagement is well established in marketing literature. However, such conceptualizations are typically applied to products rather than the services; so that relatively under-researched domain of higher education (Iglesias et al., 2019). In spite of all the arguments, higher education systems continue to engage themselves actively in the branding process. Accordingly, the researchers, in this article, focus on understanding the determinants of brand equity from the students' (customers') perspective and the present study is focusing on customer-based brand equity (CBBE) for HEIs. It is believed that the emergence of CBBE has forced HEIs to place a greater emphasis on improving their marketing strategies through social media to survive in the modern digital era.

The rising popularity of social media has offered a platform for students to meet and share their experience and enthusiasm regarding their preferred HEIs (Chugh and Ruhi, 2018). Social brand engagement opens up many new opportunities for prospective students to extract HEIs' information from existing and potential students through different social networking sites (Liu et al., 2018). The importance of increasing students' social brand engagement and sense of belonging to their institution, faculty, or department is critical to student retention (Conduit et al., 2016). Students' social engagement with HEI brands has become crucial in improving the student's enrolment rate. Social brand engagement is recognized as a predictor of HEIs success (Conduit et al., 2016). In addition, students' engagement with HEI brands has long been recognized as integral in developing a sense of belonging, social networks, and 
relationships with fellow students, facilitating persistence and degree attainment (Rutter et al., 2016) . Previous studies have indicated that students' social brand engagement is often more persuasive through social media as it is more influential in communicating brand meaning than marketing-driven, mass-targeted messages (Osei-Frimpong, 2019).

Many of the prior researchers have studied CBBE typologies on manufacturing sectors such as luxury brands (Kim and Ko, 2012; Godey et al., 2016), airline industry (Seo and Park, 2018), and retail (Çifci et al., 2016). The literature on the marketing of services conceptualizes a service such as higher education as highly complex and high in divergence (Walsh et al., 2017). But limited studies have been done on CBBE in service sectors specifically on HEIs (Herrero-Crespo et al., 2016). While the importance of CBBE for HEIs has been highlighted in the literature, a comprehensive empirical analysis of how CBBE occurs in HEIs is missing. Despite the evident importance of the CBBE, empirical research in identifying the relationship between customers' social brand engagement for CBBE has received limited attention. However, what remains unclear is how student-to-student interaction facilitates social brand engagement through social media and how it is important in creating and enhancing brand equity from the perspectives of the students of higher education (Tapanila et al., 2018). Moreover, it is unclear whether the CBBE in the emerging countries influences customers' perception towards domestic products or services as most of the previous studies of CBBE have focused only on emerged countries (Heinberg et al., 2019).

In particular, Sri Lanka, as an emerging country in Asia, strives to attract students and increase the enrolment rate in the higher education context. Sri Lankan higher education sector is trying to improve the undergraduate enrolment rate since the gross enrolment ratio reached close to $20 \%$ in 2016, placing it among the lowest rates of all emerging countries (Nedelkoska et al., 2018). Therefore, HEIs in Sri Lanka are struggling to increase the enrolment rate of the undergraduates while reducing outbound mobility. Therefore, this study is focusing on the higher education sector of Sri Lanka, and emerging country, in relating to social media adoption, and branding. Since the previous researchers have mainly focused on emerged countries in studying social media which is claimed as bias and lack of generalizable implications in emerging countries.

Therefore, the present study is centred on the extent to which social brand engagement influence undergraduates' perception of CBBE in Sri Lankan higher education sectors. In order to test the relationship between social brand engagement, and CBBE, this study further incorporated brand credibility and eWOM with the hope of enhancing generalizability. Based on the Social Information Processing Theory (SIPT), we argue that students' social brand engagement on social media induce students to rely on the expertise, and trustworthiness of the HEI brands and then to engage with eWOM (electronic word-of-mouth) activities to enhance brand equity related to HEI brands which in turn increases brand choice intention.

There are three major contributions of this study to the literature. Firstly, this study extends SITP to higher education literature to explain the influence of social brand engagement, on CBBE of HEIs, taking into consideration the role of brand credibility, and eWOM. Secondly, most previous studies about social brand engagement and CBBE have been conducted in emerged countries. Limited studies focus on these topics in emerging countries which therefore limit any generalizability of theory (Heinberg et al., 2019). Therefore, the present study aims to test the impact of social brand engagement on CBBE for HEIs in the Sri Lankan context. Finally, this study identifies the mediating effect of brand credibility, and eWOM related to higher education context which has not received attention in the literature. 


\section{Theoretical Background}

\subsection{Social Information Processing Theory}

Social Information Processing Theory (SIPT) suggested that individuals find alternative ways to gather information about the brands (Jahng and Hong, 2017), and make a judgment based on the information received from the people close to them or from the groups. An individual's behavior is usually contingent on information-processing patterns, which involve an individual's perception of social cues in the opinion community. In order to form the impression of the brands, people adapt their perceptions based on whatever information provided by others (Shan, 2016) which later leads to having a similar perception towards the brands like others. Bhaduri and Ha-Brookshire (2017) purport that customers could make judgments about the brands by referring to the information shared on social media to create a unique value about the brand in their minds.

Students' engagement with social media helps them to gather information about the HEI brands. Although social media facilitates the students to engage with their peers and HEIs, the ability of the social brand engagement in creating a unique HEI value in the minds of the students is problematic (Sim et al., 2018). Students' social engagement with their peers through different social media platforms helps them to gather information and to increase the credibility of the HEI brands while encouraging eWOM activities to provide value-rich experience in order to create brand equity from the perspectives of the students. That is students' trust in the information received from their peers and their engagement in eWOM creates a deep association with HEIs, which in turn increases HEIs' brand value and the students' positive perception about the HEI.

\subsection{Social Brand Engagement}

The recent evolution of engagement research in the marketing literature provides a broadened perspective of engagement. It recognizes that engagement extends beyond a dyadic interaction between an individual and a brand and involves a network of interactions with various others, all of which can impact the engagement with the brand (Bowden et al., 2018). Social brand engagement is a meaningful connection, creation, and communication between one consumer and one or more other consumers, using brand or brand-related language, images and meanings (Kozinets, 2014). Social brand engagement can be widened from the relationship between customer-brand to customer-customer-brand. The brand-based customer-to-customer connection can vary from the little endorsement which provides a negative critique to the higher endorsement with a higher level of appreciation and recommendation (Kozinets, 2014). Social brand engagement could be associated with the subject's self-image, which is driven by their level of belongingness to a social group (Osei-Frimpong and McLean, 2018). Social brand engagement happens as a social act in which participants to engage with the brands and other participants (Colliander et al., 2017). This engagement allows the participants to share their experience with the brand, integrate it in their expressions, and to some extent signify the brand as part of themselves (Hammedi et al., 2015). In view of this, it is essential to establish some critical factors that influence how consumers engage with a brand via social media given the psychosocial perspective of the construct.

In the education context, the engagement between the students with their peers with reference to HEI brands is beyond the direct control of the brands (Clark et al., 2017). Since HEI brands are out of the direct control, it can facilitate the individuals to interact with each other, and facilitate social brand engagement. This perspective recognizes that overall social 
brand engagement (the brand being 'the university') is a complex aggregation of engaging interactions with various others (other students or university representatives), which represents engagement between the student and the university at an institutional level (Conduit et al., 2016). In a higher education setting, social brand engagement happens when the undergraduates interact with current or potential undergraduates with reference to the HEIs, which in turn build their connection with the HEIs (Manika et al., 2019). Hence, applying these perspectives to the higher education context, social brand engagement is defined here as the student's level of interactions and connections with the brand (i.e. the university brand) based on interactions with other students with respect to that brand (Altschwager et al.,2018, p.85).

\subsection{Customer-Based Brand Equity}

The emergence of brand equity has raised the importance of marketing strategies and provided the focus for managers and researchers (Keller, 2003). Brand equity is a core concept concerning brand management and it is viewed from different perspectives (Aaker, 1996; Keller, 2003; Lassar et al., 1995; Park and Srinivasan, 1994; Simon and Sullivan, 1993; Yoo and Donthu, 2001). There is considerable debate regarding the definition of brand equity and its measurement (Yoo and Donthu, 2001). However, brand equity is accepted as the overall utility that customers place in a brand compared to its competitors (Vazquez et al., 2002).

Aaker (1992, p.28) defined brand equity as "a set of brand assets and liabilities linked to the brand's name and symbol which can subtract from, as well as add the value provided by a product or service to the customers as well as to a firm." Brand equity can be discussed from three main different perspectives; financial-based brand equity, employee-based brand equity and customer-based brand equity. Financial perspectives mainly deal with the relationship between the investment in the marketing program and the financial value of the brand to the stakeholders (Fischer and Himme, 2017). Employee-based brand equity is "the differential effect that brand knowledge has on an employee's response to their work environment" (King and Grace, 2009,p.125). Keller (2003) described brand equity as "a multidimensional concept and complex enough that many different types of measures are required. Multiple measures increase the diagnostic power of marketing research"' (p. 477). Keller (2003) noted that, from a marketing perspective, brand equity is referred to as customer-based brand equity. Since the students in higher education considered as the customers of HEIs, this study is focusing on customer-based brand equity from the perspectives of undergraduates.

Customer-based brand equity and its effect have widely been discussed in marketing literature. Keller (1993, p.8) defined customer-based brand equity as "the differential effect of brand knowledge on consumer response to the marketing of the brand". According to this definition, a brand is said to have positive (negative) customer-based brand equity if consumers react more (less) favorably to the product, price, promotion, or distribution of the brand than they do to the same marketing mix element when it is attributed to a fictitiously named or unnamed version of the product or service (Keller, 1993, p.8). Customer-based brand equity has employed to identify customers' asses to brand overall.

The role of the brand is vitally important for HEIs (Rauschnabel et al., 2016). It is considered to be the most effective way to attract prospective students. The brand of an HEI carries a promise about their services, and outcomes which influence the students' enrolment decision (Lomer et al., 2018). The level of satisfaction in a student will influence the level of customer-based brand equity. The concept of customer-based brand equity, as applied to higher education, is somewhat different from the commercial sector (Alimen and Guldem Cerit, 
2010). Most notably, branding in higher education is about who we are and is not limited to what a particular product offers the marketplace. Further, most of the previous empirical and conceptual studies of customer-based brand equity were mainly based on manufactured goods rather than services (Šerić et al., 2018). Similarly, the studies of customer-based brand equity in the higher education sector are relatively scared (Sarker et al., 2019). Customer-based brand equity is often equated to an institution's perceived value, but, that explanation is far too limiting (Soni and Govender, 2018). Therefore, this study identifies the importance of customer-based brand equity for HEIs from the perspectives of the students who are currently pursuing their higher studies in private HEIs.

\subsection{Mediating Effect of Brand Credibility and eWOM}

Brand credibility is the believability of the product position information embedded in a brand, depending on consumers' perceptions of whether the brand has the ability and willingness to continuously deliver what has been promised (Dwivedi et al., 2018). Brand credibility is a multidimensional construct that combines with expertise, and trustworthiness Kashif et al., 2018. Trustworthiness refers to the willingness of a firm to deliver what it has promised while expertise refers to the ability of a firm to deliver what it has promised (Wang and Scheinbaum, 2018). Brand credibility represents the summary of brand-to-consumer and consumer-to-brand communication over time. Brand credibility is a combination of all the prior marketing actions related to a particular brand, and to the extent these actions are consistent (Jeng, 2016). Rapid competition in the world of marketing, brand credibility may be the most important of all brand characteristics in influencing customers' brand choice (Kashif et al., 2018).

eWOM refers to any positive or negative online content made by potential, actual, or former customers through the internet or any means of information technology about a product, or company (Sijoria et al., 2019). Marketing activities through eWOM is appealing due to its ability to overcome customers' resistance, significance low cost in processing information, and fast delivery of information, especially through technology such as social media (Wakefield and Bennett, 2018). The emergence of social media has brought a new perception to eWOM by enabling internet users to communicate with other people who they already know Vermeer et al., 2019. Social media extent the practices in eWOM providing the platform to exchange ideas about the products, services, and brands with friends and acquaintances as it encourages users to have online accounts with real identities (Johnson Jorgensen and Ha, 2019).

Students who believe the HEI is willing to deliver on its promises (high trustworthiness), they have a positive feeling toward the institute and should be more likely to perceive the value endowed with HEI brand. Similarly, a student who believes the HEI's credibility could share positive comments with their peer reference to the HEI. If the students believe that the HEI can deliver on its promise of service quality (i.e., high trustworthiness), they tend to have a higher affective commitment, since trust in an HEI justifies students' positive feelings which motivate them to socially engage with HEI in order to enhance HEIs' brand equity.

eWOM, on the other hand, facilitates the students to share their views, and ideas with their peers' reference to HEIs through social networking sites. Online students' reviews and recommendations demonstrate the perspective of individuals who have experiences with the HEI. Therefore, the information shared through eWOM induced the prospective students to socially engage with the HEI brands by exhibiting the value endowed with the HEI. if the student has already chosen to socially engage with the HEI brand trough eWOM, brand 
evaluations may be the cause rather than the effect of following the brand on online social networks, which in turn enhances brand equity.

Highly socially engaged students are holistically invested in the HEI interactions (Hollebeek, 2011; D. Hollebeek and Chen, 2014) and thus develop a deep bond with the HEI brands (Dwivedi, 2015) . Consequently, students are like to have a deepen association with the HEI through their social brand engagement with the other participants in the social network. Students who tend to maintain these types of social engagement enable them to create a link with their preferred HEI, which should inevitably increase brand equity. Therefore, we propose the following hypotheses:

\section{H1: Social Brand Engagement positively influence (a) brand credibility, and (b) eWOM}

H2: (a) Brand credibility, and (b) eWOM mediates the relationship between Social Brand Engagement, and CBBE

\section{H3: (a) Brand credibility, and (b) eWOM positively influence CBBE}

\subsection{Brand Choice Intention}

The brand choice intention is the tendency that customers will select the brands and deliver their user experiences to friends and relatives (Ojiaku and Osarenkhoe, 2018). Brand choice intention represents the possibility that customers will plan (Gómez et al., 2018) or be willing to purchase a certain brand in the future (Román et al., 2018). It is the process of an individual's intention to select a brand prior to purchase (Vanwesenbeeck et al., 2017). When customers have a positive brand choice intention (Bhargave et al., 2016), this forms a positive brand commitment which propels customers to take an actual purchase action (Khan et al., 2017).

A higher level of brand equity is associated with high customer satisfaction, market share, and profits. Brand equity promotes brand preference, stimulating purchase intention. Thus, in accordance with the findings from prior research, the following assertion is hypothesized:

\section{H4: CBBE positively influence brand choice intention}

The framework designed for this study shown in Figure1. 


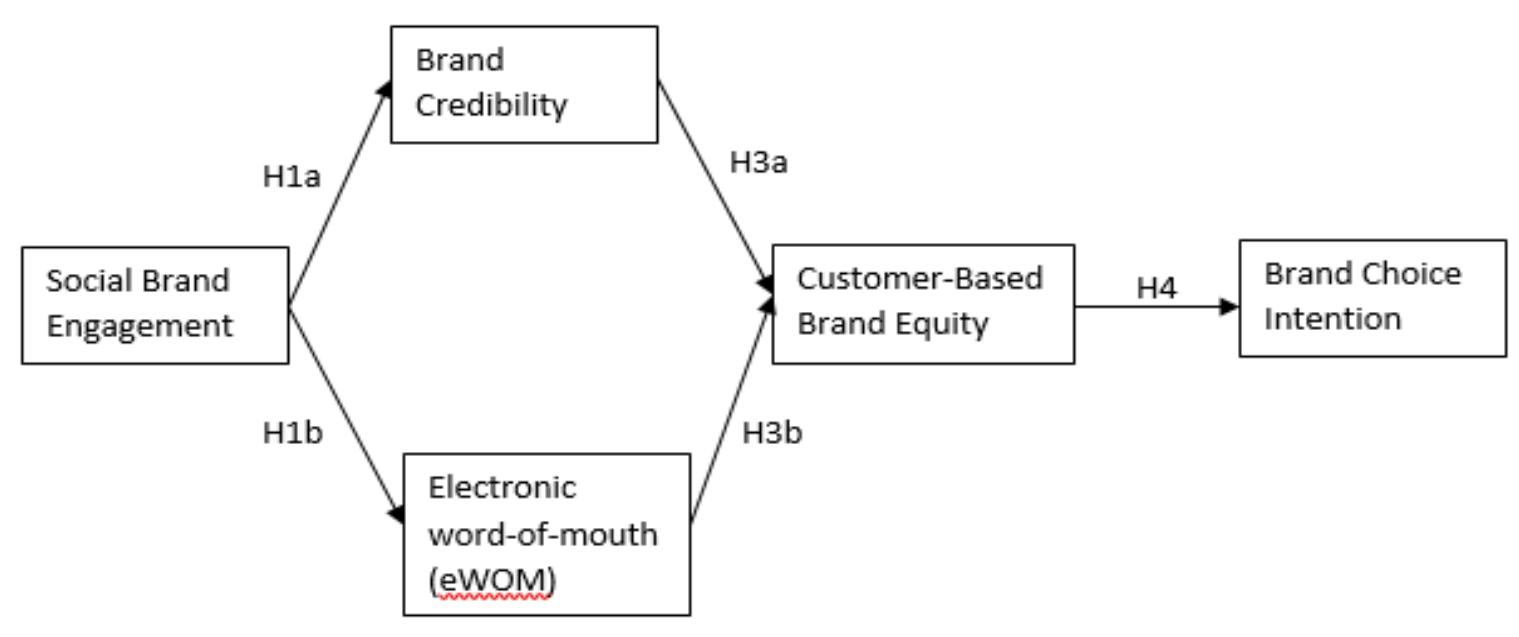

Figure1: Conceptual Framework

\section{Methodology}

In this study, only the quantitative approaches will be adopted and conform to the deductive approach. The research paradigm is based on positivism with the adoption of realist ontology that perceives reality to be objective and logical by observing causes or mechanisms driving effects in human behavior (Neuman, 2014). In addition, the positivist perspective focuses on the social pressures and situations operating on people to shape their attitude and behavior that reflects in this empirical study.

The survey method was used to collect data since surveys are considered to be the most popular form of a data collection method in quantitative studies (Saunders et al., 2009). The data collection instrument was a structured, self-administered questionnaire. The questionnaire comprised five sections that relate to SBE, CBBE, brand credibility, eWOM, and brand choice intention. Each section rated using 5 points Likert scale, where $1=$ strongly disagree, $2=$ disagree, $3=$ neutral, $4=$ agree and 5=strongly agree. Data was collected from the sample of 384 undergraduates who are currently pursuing their higher education in Sri Lankan HEIs.

Before applying statistical tools, first, reliability and validity tests were undertaken. Data were analyzed using SPSS (version 25) to perform a number of appropriate statistical techniques depending on the research question. Correlation and regression tests were used to identify how strongly selected variables were related to each other or the degree of association between the two variables (Kothari, 2004) and to predict the value of the dependent based on the known value of the independent variable, assuming that average mathematical relationship between two or more variables (Kothari, 2004). Confirmatory factor analyses were undertaken to reduce the bulk items into the manageable number and to obtain the best fit. Therefore, the present study mainly adopted SEM to obtain the best fit/confirmatory factor analysis using AMOS25.

\section{Findings}

To assess the adequacy of the measures, the authors estimated the convergent validity through: item reliability, construct reliability, and average variance extract (AVE) (see Table 1). Firstly, item reliability was evaluated based on the factor loadings of the items (i.e., 
observed variables) on their respective constructs. As all the factor loadings were higher than the threshold value of 0.5, convergent validity was supported (Hair Jr and Lukas, 2014). Secondly, construct reliability was assessed through both composite reliability (CR) values and Cronbach alpha coefficients. As all the CR values and Cronbach alpha coefficients were higher than the threshold value of 0.7, construct reliability was supported (Hair Jr and Lukas, 2014). Thirdly, the AVE was assessed because it is the summary indicator of convergence. As all the AVE values were higher than the threshold value of 0.5 , convergent validity was supported (Hair Jr and Lukas, 2014).

Table 1: Reliability and Validity measurements

\begin{tabular}{|l|l|l|l|}
\hline Constructs & Cronbach's alpha & CR & AVE \\
\hline SBE & 0.868 & 0.816 & 0.658 \\
\hline CBBE & 0.928 & 0.873 & 0.580 \\
\hline Brand Credibility (BC) & 0.875 & 0.849 & 0.763 \\
\hline eWOM & 0.828 & 0.863 & 0.644 \\
\hline Brand Choice Intention (BCI) & 0.818 & 0.763 & 0.540 \\
\hline
\end{tabular}

Further, discriminate validity was estimated to further ensure the adequacy of the measures. Discriminant validity was evaluated by comparing the square root of the AVE of each construct with the bivariate correlations among constructs (Table 2). A measurement model is considered to have acceptable discriminant validity if the square root of the AVE of each construct is higher than any of the bivariate correlations among the constructs (Iglesias et al., 2019). As all the square roots of AVE were higher than the bivariate correlations among the constructs, discriminant validity was supported (Iglesias et al., 2019)

Table 2: Discriminate Validity

\begin{tabular}{|l|l|l|l|l|l|}
\hline & SBE & CBBE & BC & eWOM & BCI \\
\hline SBE & $\mathbf{0 . 7 8 4}^{\mathbf{a}}$ & & & & \\
\hline CBBE & $0.316^{\mathrm{b}}$ & $\mathbf{0 . 7 8 1}^{\mathbf{a}}$ & & & \\
\hline BC & 0.415 & 0.515 & $\mathbf{0 . 7 5 3}^{\mathbf{a}}$ & & \\
\hline eWOM & -0.042 & 0.010 & 0.163 & $\mathbf{0 . 8 2 0}^{\mathbf{a}}$ & \\
\hline BCI & -0.218 & -0.078 & -0.177 & -0.256 & $\mathbf{0 . 8 1 2}^{\mathbf{a}}$ \\
\hline
\end{tabular}

a Square root of AVE in the diagonal

b Pearson correlations among constructs

In order to assess model fit, the comparative fit index with the overall model chi-square measure $(\chi 2)$, the comparative fit index (CFI), the goodness of fit index (GFI), the root mean square error of approximation (RMSEA), and Associated PCLOSE were used (Byrne, 2010). For the current model, $\chi 2$ /df is $1.052(\chi 2=88.336$; $\mathrm{df}=84)$, CFI is .978, GFI is .902, AGFI 
is .905, RMSEA is .042, and Associated PCLOSE is 0. 887.An adequate model fit was, therefore, indicated.

Having successfully validated the structural model's goodness-of-fit to the data, the next step was to examine the research hypotheses using path measurement coefficients (regression weight estimates and critical ratios) from the SEM analysis performed with AMOS 25. Table 3 on the summaries these results, from which it is seen that hypothesized causal paths in the structural model were significant at the 0.05 level.

Table 3: Path Coefficient Weights for the Structural Model

\begin{tabular}{|l|l|l|l|l|}
\hline Hypotheses & Estimates & CR & p-value & Comment \\
\hline SBE-> BC & 0.346 & 2.243 & 0.015 & Supported \\
\hline $\begin{array}{l}\text { SBE-> } \\
\text { eWOM }\end{array}$ & 0.179 & 2.354 & 0.001 & Supported \\
\hline $\begin{array}{l}\text { BC-> } \\
\text { CBBE }\end{array}$ & 0.438 & 3.518 & $* * *$ & Supported \\
\hline $\begin{array}{l}\text { eWOM-> } \\
\text { CBBE }\end{array}$ & 0.422 & 4.521 & $* * *$ & Supported \\
\hline $\begin{array}{l}\text { CBBE-> } \\
\text { BCI }\end{array}$ & 0.287 & 3.902 & 0.001 & Supported \\
\hline
\end{tabular}

At a significance level of 0.05 , the estimated values empirically support all the direct effects that are part of the hypothesized model. Table 3 presents the standardized path estimates and t-values for each of the hypothesized model relationships for each construct. Concerning the structural relationships proposed in the conceptual model SBE, brand credibility, and eWOM, had a significant relationship with CBBE toward the higher education sector supporting H1(a), H1(b), H3(a), and H3(b). Based on the standardized estimates between paths, association with CBBE had a significant influence on brand choice intention supporting the hypotheses $\mathrm{H} 4$.

Further, the correlation between the SBE-CBBE, SBE-BCI, CBBE-BCI variables was $0.541,0.671,0.628$ respectively, indicating a moderate positive relationship among them. The R-Square among SBE and CBBE were $0.42 .42 \%$ of the variance in the SBE was explained by CBBE. Furthermore, the R-Square among SBE and BCI was $0.36 .36 \%$ of the variance in the SBE was explained by purchase intention. The R-Square among CBBE and BCI were 0.47. 47 $\%$ of the variance in CBBE was explained by BCI.

When the new predictor, the brand credibility, was included, the Adjusted R-square value changed $0.591 .59 .1 \%$ of the variance in the SBE was explained by CBBE and BCI. The Beta value (standardized) of the new predictor (BC) has increased to 0.64 and it was significant (sigvalue $=0.000$ ).

Similarly, eWOM was included, the Adjusted R-square value changed $0.574 .57 .4 \%$ of the variance in the SBE was explained by CBBE and BCI. The Beta value (standardized) of the new predictor (eWOM) has increased to 0.72 and it was significant (sig-value $=0.000$ ).

In addition to this, the mediating effect of $\mathrm{BC}$, and eWOM between SBE and CBBE had analyzed (Table 4).

Table 4: Mediating effect of brand trust, and brand co-creation 


\begin{tabular}{|l|l|l|l|}
\hline Path & $\begin{array}{l}\text { Direct } \\
\text { Effect }\end{array}$ & Indirect Effect & Mediation \\
\hline SBE-> BC-> CBBE & $0.0042(0.9758)$ & $0.3836^{* * *}$ & Full Mediation \\
\hline SBE-> eWOM->CBBE & $-0.5734(0.5237)$ & $0.1245^{* * *}$ & Full Mediation \\
\hline
\end{tabular}

In the present study, the $95 \%$ confidence interval of the indirect effects was obtained with 5000 bootstraps resamples (Preacher \& Hayes, 2008). Results showed that the direct effect between SBE and CBBE was $\mathrm{B}=0.0042(\mathrm{p}=0.9758)$ which is not significant. In addition, results indicated that the indirect effect became significant after including $\mathrm{BC}$ as the mediating variable $(\mathrm{B}=0.3836, \mathrm{p}=0.000)$, which indicates a Full mediating effect of Supporting H2a. Similarly, the direct effect between SBE and eWOM was $B=-0.5734(p=0.5237)$ which is not significant. In addition, results indicated that the indirect effect became significant after including eWOM as the mediating variable $(\mathrm{B}=0.1245, \mathrm{p}=0.000)$, which indicates a Full mediating effect of Supporting H2b.

\section{Discussion and Conclusion}

The primary purpose of this study was to test the relationship between SBE, CBBE, and BCI perceived by undergraduates related to the higher education sector. In this process, the researcher has mainly focused on developing a conceptual framework including mediating variables which are the brand credibility, and eWOM among SBE and CBBE. The conceptual model was developed based on the critical review of previous literature and in consideration of the main research question and research objectives. Furthermore, five hypotheses were developed to demonstrate the relationship between the main constructs of the research model. The results show that all the constructs in the framework have a significant positive relationship with each other.

Through the examination of the role of SBE in creating CBBE using social information processing theory, this study contributes to a deeper understanding of the undergraduate's engagement with brands in social media in Sri Lanka and its impact on the formation of CBBE and brand choice intention. The theoretical model and corresponding hypotheses were addressed the research objectives posed in this study. The outcome of the data analysis indicated that a relationship between SBE, CBBE, brand credibility, eWOM, and brand choice intention exists at a significant level. Furthermore, the variance among SBE and CBBE was able to explain with a higher percentage including the brand credibility, and eWOM as mediating variables. Moreover, introducing modifications, the theoretical model was developed with overall goodness-of-fit to an acceptable level.

This study raises some theoretical and practical implications. First, this study enhances the understanding of the antecedents of CBBE and its relationship with SBE. Second, the proposed theoretical framework identifies determinants of SBE, CBBE, and brand choice intention in the higher education sector incorporating the brand credibility, and eWOM which have not yet been explored. Finally, this study further extends the SIPT to higher education literature while contributing to the marketing literature in emerging countries.

In terms of managerial contribution, the findings of this study provide HEIs' marketing managers to understand the influence of SBE in social media on CBBE and its effect on HEIs' choice intention. This further, allows us to understand the importance of SBE in social media, and thus to develop better marketing strategies to motivate the users to create more content in social media. As SBE impacts important behavioral outcomes, it is clear brands need to monitor what consumers are saying. Monitoring SBE provides opportunities for brand management to 
identify what consumers are saying about the brand and how does that compare to what they are saying about the brand's competitors. Therefore, it could provide insight into the possible brand development opportunities, important areas to focus on reputation management, and customer-brand relationship building and management.

\section{References}

AAKER, D. A. 1992. The value of brand equity. Journal of business strategy, 13, 27-32.

AAKER, D. A. 1996. Measuring brand equity across products and markets. California management review, 38.

ALIMEN, N. \& GULDEM CERIT, A. 2010. Dimensions of brand knowledge: Turkish university students' consumption of international fashion brands. Journal of Enterprise Information Management, 23, 538-558.

ALTSCHWAGER, T., DOLAN, R. \& CONDUIT, J. 2018. Social brand engagement: How orientation events engage students with the university. Australasian Marketing Journal (AMJ), 26, 83-91.

ÁLVAREZ-MENDIOLA, G. \& GONZÁLEZ-LEDESMA, M. A. 2018. Marketing context and branding content of private universities in Chile and Mexico. Competition in Higher Education Branding and Marketing. Springer.

BHADURI, G. \& HA-BROOKSHIRE, J. 2017. The role of brand schemas, information transparency, and source of message on apparel brands' social responsibility communication. Journal of Marketing Communications, 23, 293-310.

BHARGAVE, R., MANTONAKIS, A. \& WHITE, K. 2016. The cue-of-the-cloud effect: When reminders of online information availability increase purchase intentions and choice. Journal of Marketing Research, 53, 699-711.

BOWDEN, J. L. H., CONDUIT, J., HOLLEBEEK, L. D., LUOMA- AHO, V. \& SOLEM, B. A. A. 2018. The role of social capital in shaping consumer engagement within online brand communities. The Handbook of Communication Engagement, 491-504.

CHUGH, R. \& RUHI, U. 2018. Social media in higher education: A literature review of Facebook. Education and Information Technologies, 23, 605-616.

ÇIFCI, S., EKINCI, Y., WHYATT, G., JAPUTRA, A., MOLINILLO, S. \& SIALA, H. 2016. A cross validation of Consumer-Based Brand Equity models: Driving customer equity in retail brands. Journal of Business Research, 69, 3740-3747.

CLARK, M., FINE, M. B. \& SCHEUER, C.-L. 2017. Relationship quality in higher education marketing: the role of social media engagement. Journal of Marketing for Higher Education, 27, 40-58.

COLLIANDER, J., MARDER, B., FALKMAN, L. L., MADESTAM, J., MODIG, E. \& SAGFOSSEN, S. 2017. The social media balancing act: Testing the use of a balanced self-presentation strategy for politicians using twitter. Computers in Human Behavior, 74, 277-285.

CONDUIT, J., KARPEN, I. O. \& FARRELLY, F. 2016. Student engagement: a multiple layer phenomenon. Making a Difference Through Marketing. Springer.

D. HOLLEBEEK, L. \& CHEN, T. 2014. Exploring positively-versus negatively-valenced brand engagement: a conceptual model. Journal of Product \& Brand Management, 23, $62-74$. 
DWIVEDI, A. 2015. A higher-order model of consumer brand engagement and its impact on loyalty intentions. Journal of Retailing and Consumer Services, 24, 100-109.

DWIVEDI, A., NAYEEM, T. \& MURSHED, F. 2018. Brand experience and consumers' willingness-to-pay (WTP) a price premium: Mediating role of brand credibility and perceived uniqueness. Journal of Retailing and Consumer Services, 44, 100-107.

ENDO, A. C. B., DE FARIAS, L. A. \& COELHO, P. S. 2019. Service branding from the perspective of higher education administrators. Marketing Intelligence \& Planning.

FISCHER, M. \& HIMME, A. 2017. The financial brand value chain: How brand investments contribute to the financial health of firms. International Journal of Research in Marketing, 34, 137-153.

GODEY, B., MANTHIOU, A., PEDERZOLI, D., ROKKA, J., AIELLO, G., DONVITO, R. \& SINGH, R. 2016. Social media marketing efforts of luxury brands: Influence on brand equity and consumer behavior. Journal of business research, 69, 5833-5841.

GÓMEZ, M., IMHOFF, B., MARTÍN-CONSUEGRA, D., MOLINA, A. \& SANTOSVIJANDE, M. L. 2018. Language tourism: The drivers that determine destination choice intention among US students. Tourism management perspectives, 27, 125-135.

GUILBAULT, M. 2018. Students as customers in higher education: The (controversial) debate needs to end. Journal of Retailing and Consumer Services, 40, 295-298.

HAIR JR, J. F. \& LUKAS, B. (2014). Marketing research, McGraw-Hill Education Australia.

HAMMEDI, W., KANDAMPULLY, J., ZHANG, T. T. \& BOUQUIAUX, L. 2015. Online customer engagement: Creating social environments through brand community constellations. Journal of service management, 26, 777-806.

HEINBERG, M., KATSIKEAS, C. S., OZKAYA, H. E. \& TAUBE, M. 2019. How nostalgic brand positioning shapes brand equity: differences between emerging and developed markets. Journal of the Academy of Marketing Science, 1-22.

HERRERO-CRESPO, Á., SAN MARTÍN GUTIÉRREZ, H. \& GARCIA-SALMONES, M. D. M. 2016. Influence of country image on country brand equity: Application to higher education services. International Marketing Review, 33, 691-714.

HOLLEBEEK, L. 2011. Exploring customer brand engagement: definition and themes. Journal of strategic Marketing, 19, 555-573.

IGLESIAS, O., MARKOVIC, S. \& RIALP, J. 2019. How does sensory brand experience influence brand equity? Considering the roles of customer satisfaction, customer affective commitment, and employee empathy. Journal of Business Research, 96, 343354.

JAHNG, M. R. \& HONG, S. 2017. How should you tweet?: The effect of crisis response voices, strategy, and prior brand attitude in social media crisis communication. Corporate Reputation Review, 20, 147-157.

JENG, S.-P. 2016. The influences of airline brand credibility on consumer purchase intentions. Journal of Air Transport Management, 55, 1-8.

JOHNSON JORGENSEN, J. \& HA, Y. 2019. The Influence of Electronic Word of Mouth via Social Networking Sites on the Socialization of College-Aged Consumers. Journal of Interactive Advertising, 19, 29-42.

KASHIF, M., FERNANDO, P., SAMAD, S. \& THURASAMY, R. 2018. Finding greener grass on the other side of hill: Examining donor perceived brand equity in a moderating role of brand credibility. Asia Pacific Journal of Marketing and Logistics, 30, 9881012. 
KAUSHAL, V. \& ALI, N. 2019. A Structural Evaluation of University Brand Equity Dimensions: Evidence from Private Indian University. International Journal of Customer Relationship Marketing and Management (IJCRMM), 10, 1-20.

KELLER, K. L. 1993. Conceptualizing, measuring, and managing customer-based brand equity. Journal of marketing, 57, 1-22.

KELLER, K. L. 2003. Brand synthesis: The multidimensionality of brand knowledge. Journal of consumer research, 29, 595-600.

KHAN, N. J., RAZZAQUE, M. A. \& HAZRUL, N. M. 2017. Intention of and commitment towards purchasing luxury products: A study of Muslim consumers in Malaysia. Journal of Islamic Marketing, 8, 476-495.

KIM, A. J. \& KO, E. 2012. Do social media marketing activities enhance customer equity? An empirical study of luxury fashion brand. Journal of Business Research, 65, 1480-1486.

KING, C. \& GRACE, D. 2009. Employee based brand equity: A third perspective. Services Marketing Quarterly, 30, 122-147.

KOTHARI, C. R. 2004. Research methodology: Methods and techniques, New Age International.

KOZINETS, R. V. 2014. Social brand engagement: A new idea. GfK Marketing Intelligence Review, 6, 8 .

LASSAR, W., MITTAL, B. \& SHARMA, A. 1995. Measuring customer-based brand equity. Journal of consumer marketing, 12, 11-19.

LEIJERHOLT, U., CHAPLEO, C. \& O'SULLIVAN, H. 2019. A brand within a brand: an integrated understanding of internal brand management and brand architecture in the public sector. Journal of Brand Management, 26, 277-290.

LIU, R. L., SPROTT, D. E., SPANGENBERG, E. R., CZELLAR, S. \& VOSS, K. E. 2018. Consumer preference for national vs. private brands: The influence of brand engagement and self-concept threat. Journal of Retailing and Consumer Services, 41, 90-100.

LOMER, S., PAPATSIBA, V. \& NAIDOO, R. 2018. Constructing a national higher education brand for the UK: positional competition and promised capitals. Studies in Higher Education, 43, 134-153.

M'ZUNGU, S., MERRILEES, B. \& MILLER, D. 2019. Strategic and operational perspectives of SME brand management: A typology. Journal of Small Business Management, 57, 943-965.

MANIKA, D., GREGORY-SMITH, D., WELLS, V. K. \& TROMBETTI, E. 2019. 'Student Switch Off!': how do university students respond to a corporate-sponsored proenvironmental social marketing campaign? Studies in Higher Education, 44, 16911706.

NEDELKOSKA, L., O'BRIEN, T. \& STOCK, D.2018.Does the Sri Lankan economy need more university graduates? Centre for International Development at Harvard University

NEUMAN, W. L. \& ROBSON, K. (2014). Basics of social research, Pearson Canada Toronto.

OJIAKU, O. C. \& OSARENKHOE, A. 2018. Determinants of customers' brand choice and continuance intentions with mobile data service provider: The role of past experience. Global Business Review, 19, 1478-1493.

ÖKTEN, N. Z., OKAN, E. Y., ARSLAN, Ü. \& GÜNGÖR, M. Ö. 2019. The effect of brand value on economic growth: A multinational analysis. European Research on Management and Business Economics, 25, 1-7. 
OSEI-FRIMPONG, K. 2019. Understanding consumer motivations in online social brand engagement participation: Implications for retailers. International Journal of Retail \& Distribution Management, 47, 511-529.

OSEI-FRIMPONG, K. \& MCLEAN, G. 2018. Examining online social brand engagement: A social presence theory perspective. Technological Forecasting and Social Change, 128, $10-21$.

OTTMAN, J. 2017. The new rules of green marketing: Strategies, tools, and inspiration for sustainable branding, Routledge.

PARK, C. S. \& SRINIVASAN, V. 1994. A survey-based method for measuring and understanding brand equity and its extendibility. Journal of marketing research, 31, 271-288.

RAUSCHNABEL, P. A., KREY, N., BABIN, B. J. \& IVENS, B. S. 2016. Brand management in higher education: the university brand personality scale. Journal of Business Research, 69, 3077-3086.

ROMÁN, S. \& SÁNCHEZ-SILES, L. M. 2018. Parents' choice criteria for infant food brands: A scale development and validation. Food Quality and Preference, 64, 1-10.

RUTTER, R., ROPER, S. \& LETTICE, F. 2016. Social media interaction, the university brand and recruitment performance. Journal of Business Research, 69, 3096-3104.

SARKER, M. M., MOHD-ANY, A. A. \& KAMARULZAMAN, Y. 2019. Conceptualising consumer-based service brand equity (CBSBE) and direct service experience in the airline sector. Journal of Hospitality and Tourism Management, 38, 39-48.

SAUNDERS, M., LEWIS, P. \& THORNHILL, A. 2009. Research methods for business students. Essex. Financial Times/Prentice Hall.

SEO, E.-J. \& PARK, J.-W. 2018. A study on the effects of social media marketing activities on brand equity and customer response in the airline industry. Journal of Air Transport Management, 66, 36-41.

ŠERIĆ, M., MIKULIĆ, J. \& GIL-SAURA, I. 2018. Exploring relationships between customerbased brand equity and its drivers and consequences in the hotel context. An impactasymmetry assessment. Current Issues in Tourism, 21, 1621-1643.

SHAN, Y. 2016. How credible are online product reviews? The effects of self-generated and system-generated cues on source credibility evaluation. Computers in Human Behavior, 55, 633-641.

SIJORIA, C., MUKHERJEE, S. \& DATTA, B. 2019. Impact of the antecedents of electronic word of mouth on consumer based brand equity: a study on the hotel industry. Journal of Hospitality Marketing \& Management, 28, 1-27.

SIM, M., CONDUIT, J. \& PLEWA, C. 2018. Engagement within a service system: a fuzzy set analysis in a higher education setting. Journal of Service Management, 29, 422-442.

SIMON, C. J. \& SULLIVAN, M. W. 1993. The measurement and determinants of brand equity: A financial approach. Marketing science, 12, 28-52.

SONI, S. \& GOVENDER, K. 2018. The Relationship between Service Quality Dimensions and Brand Equity: Higher Education Students' Perceptions. Journal of Management and Business Administration. Central Europe, 26, 71-87.

TAPANILA, K., SIIVONEN, P. \& FILANDER, K. 2018. Academics' social positioning towards the restructured management system in Finnish universities. Studies in Higher Education, 1-12. 
VANWESENBEECK, I., WALRAVE, M. \& PONNET, K. 2017. Children and advergames: the role of product involvement, prior brand attitude, persuasion knowledge and game attitude in purchase intentions and changing attitudes. International Journal of Advertising, 36, 520-541.

VAZQUEZ, R., DEL RIO, A. B. \& IGLESIAS, V. 2002. Consumer-based brand equity: development and validation of a measurement instrument. Journal of Marketing management, 18, 27-48.

VERMEER, S. A., ARAUJO, T., BERNRITTER, S. F. \& VAN NOORT, G. 2019. Seeing the wood for the trees: How machine learning can help firms in identifying relevant electronic word-of-mouth in social media. International Journal of Research in Marketing.

WAKEFIELD, L. T. \& BENNETT, G. 2018. Sports fan experience: Electronic word-of-mouth in ephemeral social media. Sport Management Review, 21, 147-159.

WALSH, G., SCHAARSCHMIDT, M. \& IVENS, S. 2017. Effects of customer-based corporate reputation on perceived risk and relational outcomes: empirical evidence from gender moderation in fashion retailing. Journal of Product \& Brand Management, 26, 227-238.

WANG, S. W. \& SCHEINBAUM, A. C. 2018. Enhancing brand credibility via celebrity endorsement: Trustworthiness trumps attractiveness and expertise. Journal of Advertising Research, 58, 16-32.

YOO, B. \& DONTHU, N. 2001. Developing and validating a multidimensional consumerbased brand equity scale. Journal of business research, 52, 1-14. 